\title{
INADEQUATE REASONS: \\ The NeEd For TRIBUNAL PARTICIPATION IN JUDICIAL REVIEW LITIGATION
}

\author{
LORNE NEUDORF ${ }^{*}$
}

\section{INTRODUCTION}

Canadian courts continue to grapple with the implications of a broadly applicable obligation on administrative decision makers to provide reasons as part of the common law duty of procedural fairness, established by the Supreme Court of Canada in its 1992 judgment in Baker v. Canada (Minister of Citizenship and Immigration). ${ }^{1}$ The requirement for reasons, which applies when a decision of a public body has "important significance for the individual, when there is a statutory right of appeal, or in other circumstances," "2 has prompted a more forgiving judicial approach to what is proffered by the decision maker as its reasons. In the Baker case, for instance, the shorthand notes of a junior investigating officer were treated by the Supreme Court of Canada as fulfilling the requirement for reasons in relation to a decision to deny an immigration claim on humanitarian and compassionate grounds. Although the officer's notes were not well-organized or comprehensive, they were seen to meet the requirement for reasons on the basis that the reviewing court must adopt a pragmatic approach and "evaluate the requirements of the duty of fairness with recognition of the day-to-day realities of administrative agencies.",3

Since Baker, courts have continued to expand what counts as reasons when reasons are required by the duty of procedural fairness. In Newfoundland and Labrador Nurses' Union v. Newfoundland and Labrador (Treasury Board), for example, the Supreme Court of Canada held that the poor quality of reasons provided by an administrative decision maker could not be a stand-alone basis upon which to quash a decision for lacking fairness. ${ }^{4}$ Instead, the question under procedural fairness focused simply on whether any reasons were provided when reasons were required. The quality of reasons would be considered as part of a substantive review when applying a reasonableness standard. In other words, most anything proffered by the decision maker as reasons will count as "ticking the box" when reasons are legally required. It is only when testing the reasonableness of the outcome that courts will pay closer attention to the quality and comprehensiveness of the reasons provided. And even in those circumstances, reviewing courts will apply a generous interpretation of the reasons, going so far as to judicially supplement inadequate or incomplete reasons to uphold the decision if the court can find a reasonable basis for it. According to the Supreme Court of Canada, courts should adopt a "respectful attention to the reasons offered or which could be offered in support of a decision."

JD (Victoria), LLM (McGill), PhD (Cambridge); Member of the Law Society of Upper Canada; Assistant Professor, Thompson Rivers University, Faculty of Law.

Baker v Canada (Minister of Citizenship and Immigration), [1999] 2 SCR 817 [Baker].

Ibid at para 43 .

Ibid at para 44

2011 SCC 62, [2011] 3 SCR 708 at para 14 [Newfoundland Nurses’ Union].

Ibid at para 12, citing David Dyzenhaus, "The Politics of Deference: Judicial Review and Democracy" in Michael Taggart, ed, The Province of Administrative Law (Oxford: Hart, 1997) 279 at 286 [emphasis added]. See also Mary Liston, "Governments in Miniature: The Rule of Law in the Administrative State" in Colleen M Flood \& Lorne Sossin, eds, Administrative Law in Context, 2nd ed (Toronto: Emond 
Alberta (Information and Privacy Commissioner) v. Alberta Teachers' Association ${ }^{6}$ provides an illustration of the court filling in the blanks, or more accurately, devising hypothetical reasons that could have been provided by the decision maker when none were actually provided. In that case, the decision maker failed to consider the issue of whether a time limit could be properly extended after the time had already elapsed as none of the parties had bothered to question it. The agency simply proceeded on the assumption that it could provide such an extension. The issue was later raised on judicial review for the first time. The Supreme Court of Canada upheld the reasonableness of the agency's "implicit" decision to extend the time limit after engaging in a thought experiment to consider reasons that could have been offered by the agency, had it turned its mind to the issue. While the Supreme Court of Canada cautioned that reviewing courts should give due regard to reasons provided by the decision maker without ignoring or glossing over clear deficiencies or problematic lines of reasoning, they should also seek to supplement inadequate or incomplete reasons if there exists a reasonable basis (from the reviewing court's perspective) for the decision. ${ }^{7}$ Again, the rationale is principally pragmatic. Pausing judicial review litigation to request better or more complete reasons from the decision maker could "undermine the goal of expedient and cost-efficient decision making." 8 The decision was also somewhat punitive on the facts as the parties had an opportunity to raise time limits before the agency but failed to do so. Allowing parties to raise an issue for the first time on judicial review that could have been raised before the decision maker would deprive the court of the benefit of an express decision made by the agency and reasons for that decision, effectively shortcircuiting the administrative decision-making process. ${ }^{9}$

The recent Supreme Court of Canada judgment in Ontario (Energy Board) v. Ontario Power Generation Inc. ${ }^{10}$ is another case that considers deficient reasons provided by a public authority. The case raised the important question of whether the original reasons supplied by a tribunal could be later "topped up" by the tribunal itself as a party to a judicial review litigation. Relatedly, the more general question arose as to the proper role of a tribunal on a statutory appeal or judicial review of its decision and to what extent the tribunal could act "aggressively" in defending its original decision. In answering these questions, the Supreme Court of Canada established in law the proper participatory role of a public body before a reviewing court and the acceptable content of arguments that could be made by the decision maker before the court.

Montgomery, 2013) 39 at 76-78, discussing the adequacy of reasons and noting Lake $v$ Canada (Minister of Justice), 2008 SCC 23, [2008] 1 SCR 761 at paras 46-48 (brief ministerial reasons in relation to extradition decision were seen as adequate in discharging the duty of procedural fairness and could also be seen to justify the decision as reasonable under substantive review).

2011 SCC 61, [2011] 3 SCR 654.

Ibid at para 55 .

Ibid.

Notably, the duty of procedural fairness could not be properly applied to the "implicit" decision as there would be no reasons in relation to the agency simply proceeding with its work. In effect, this means that the requirement for reasons under the duty of procedural fairness could be abrogated by substantive review in a case where the court can devise hypothetical reasons to justify the outcome to uphold the decision as reasonable.

$10 \quad$ Ontario (Energy Board) v Ontario Power Generation Inc, 2015 SCC 44, [2015] 3 SCR 147 [Ontario (Energy Board)]. 


\section{THE JUDGMENT}

\section{A. FACTUAL BACKGROUND}

The appeal arose in relation to a decision of the Ontario Energy Board, a public authority charged with establishing utility rates in Ontario. As part of its rate setting process, the Board was statutorily required to factor "just and reasonable" expenses incurred by utility providers into the applicable rate. For the 2011 to 2012 operating period, Ontario Power Generation, a large government-owned electricity production company, sought an increase of electricity rates in relation to costs that it had incurred for its operations. The Board rejected $\$ 145$ million of labour costs for Ontario Power Generation's nuclear facilities on the basis that these costs were excessive.

On a statutory appeal of the Board's decision to the Ontario Divisional Court, Ontario Power Generation argued that the Board had improperly failed to include these expenses in setting the electricity rate. In responding to the notice of appeal, the Board sought to fully participate in the proceedings as a litigation party and made a number of arguments to further justify its original decision. At the Supreme Court of Canada, Ontario Power Generation challenged the role of the Board in the appeal and argued that the Board had improperly engaged in "bootstrapping" in relation to its original decision by using the appeal as a fresh opportunity to supplement its original reasons. The respondent Power Workers' Union also argued that "the Board's detailed and aggressive defence of the merits of its decision"11 offended the principle of administrative impartiality. The union took aim at the Board's submission that there was little point in the Supreme Court of Canada hearing the appeal as it would end up deciding the case in the same way if its original decision was quashed. According to the union, "[s]uch pre-judging is improper and unseemly, and should not be heard by the Court." 12 The union also argued that the Board's arguments on appeal were "inconsistent with the Board's actual reasons" provided at the time the rate setting decision was made. ${ }^{13}$ Similarly, Ontario Power Generation argued that the Board's arguments before the courts were "late-blooming justifications" that rested "substantially on reasoning not contained in the [original] decision, and on facts that it did not find."14

\section{B. Tribunal Participation in ReView Litigation}

Writing for a majority of the Supreme Court of Canada, Justice Rothstein rejected Ontario Power Generation's challenge to the Board's participation in the appeal. At the outset of his analysis, Justice Rothstein reviewed a number of past cases in relation to the participation of public bodies in statutory appeals and judicial review litigation. He observed that the Supreme Court of Canada had previously identified concerns with the aggressive participation of administrative decision makers on judicial review, which could serve to

Ontario (Energy Board), ibid (Factum of the Respondent, Power Workers' Union of Public Employees, Local 1000 at para 47).

Ibid.

Ibid at para 48.

Ontario (Energy Board), supra note 10 (Factum of the Respondent, Ontario Power Generation Inc at para 77). 
discredit perceptions of their impartiality. ${ }^{15}$ Other cases had noted the importance of a principle of administrative finality in that a public body should no longer be able to speak to a decision after it had been made. ${ }^{16}$ Courts had also recognized, however, that public bodies could assist the reviewing court in understanding the record below and by drawing attention to considerations that related to the specialized expertise of the decision maker. ${ }^{17}$ This role would be particularly important in relation to a reasonableness review of an administrative decision to ensure that the reviewing court was fully informed in assessing the reasonableness of the outcome.

After looking at the past cases, Justice Rothstein held that there should be no categorical ban on the participation of a public body in an appeal or judicial review. Instead, a discretionary approach should be adopted which would permit the participation of administrative decision makers when it could help the reviewing court arrive at just outcomes. ${ }^{18}$ According to Justice Rothstein, public bodies are often well-positioned to help the court interpret specialized statutory provisions and better appreciate "factual and legal realities." 19 The full participation of a public body in litigation may also be a practical necessity in a case where there is no other informed party to oppose the application, ensuring the court hears both sides of the dispute..$^{20}$ In considering whether it is appropriate to permit the participation of a public body in an appeal or judicial review litigation, the reviewing court should consider statutory provisions related to the decision maker's structure, processes, and role. Concerns related to impartiality might be less important in some circumstances. $^{21}$ If a reading of the enabling legislation does not resolve the question of participation, the court must exercise its discretion and strike a balance between the goals of fully informed adjudication and the maintenance of administrative impartiality. ${ }^{22}$ In particular, reviewing courts should consider three factors:

(1) If an appeal or review were to be otherwise unopposed, a reviewing court may benefit by exercising its discretion to grant tribunal standing.

(2) If there are other parties available to oppose an appeal or review, and those parties have the necessary knowledge and expertise to fully make and respond to arguments on appeal or review, tribunal standing may be less important in ensuring just outcomes.

(3) Whether the tribunal adjudicates individual conflicts between two adversarial parties, or whether it instead serves a policy-making, regulatory or investigative role, or acts on behalf of the public interest, bears on the degree to which impartiality concerns are raised. Such concerns may weigh more heavily where the tribunal served an adjudicatory function in the proceeding that is the subject

Ontario (Energy Board), supra note 10 at para 41 citing Northwestern Utilities Ltd v Edmonton (City of), [1979] 1 SCR 684 at 709.

Canada (Attorney General) v Quadrini, 2010 FCA 246, [2012] 2 FCR 3 [Quadrini].

Ontario (Energy Board), supra note 10 at para 44, citing BCGEU V Indust Rel Council (1988), 26 BCLR

(2d) 145 (CA) at 153.

Ontario (Energy Board), ibid at para 53.

Ibid.

Ibid at para 54

Ibid at para 55.

Ibid at para 57. 
of the appeal, while a proceeding in which the tribunal adopts a more regulatory role may not raise such concerns. ${ }^{23}$

Applying the law to the facts of the case, Justice Rothstein observed that the enabling legislation provided the Board with a right to be heard in an appeal but fell short of specifying its role in the appeal. The Court therefore had to exercise its discretion to determine what role the Board should play. According to Justice Rothstein, it was proper for the Board to appear before the Court to make arguments in favour of its original decision. ${ }^{24}$ In applying the three factors, Justice Rothstein observed that the Board was the only respondent that could offer a well-informed opposing view to the court challenge and that it was therefore needed to defend the reasonableness of its decision. ${ }^{25}$ In addition, the Board had a broad mandate to regulate utilities and carried out a number of different roles under its enabling legislation. In setting utility rates, the Board exercised a regulatory role and took into account a variety of considerations. This process was substantially different from an adversarial judicial process, which minimized concerns that the participation of the Board as a party to the appeal would diminish perceptions of the Board's impartiality. ${ }^{26}$

\section{TRIBUnAL "BoOtSTRAPPING" IN REVIEW Litigation}

Although the Board could participate as a party to the statutory appeal to defend the reasonableness of its decision, the Supreme Court of Canada went on to consider the appropriate content of the Board's arguments before the Court. As noted earlier, the respondents submitted that the Board made arguments that amounted to improper bootstrapping in relation to its original decision. According to Justice Rothstein, bootstrapping in Canadian law is understood to occur when a public body uses an appeal or judicial review to supplement a deficient decision with new arguments that it did not rely on in making its original decision. ${ }^{27}$ Two lines of authority on whether bootstrapping should be permitted were apparent from the case law. On the one hand, courts have held that the principle of administrative finality provides that once a public body has made a decision and provided its reasons, its job with respect to that matter is finished. It could not use a judicial process as an opportunity to "amend, vary, qualify or supplement" its reasons. ${ }^{28}$ The only exception would be where the enabling legislation permitted the decision maker to vary its decision or hold a rehearing. On the other hand, courts have held that new arguments could be made by a public body on judicial review if the arguments were consistent with the original reasons given for its decision. ${ }^{29}$

Justice Rothstein observed that both positions held merit. By allowing a public body to make new arguments on appeal or judicial review, the court would be presented with the best arguments for each side, which serves the interests of justice. ${ }^{30}$ Permitting bootstrapping,

Ibid at para 59.

Ibid at para 60.

Ibid.

Ibid at para 61.

Ibid at para 64

Ibid at para 65, quoting Quadrini, supra note 16 at 5. See also Chandler v Alberta Association of Architects, [1989] 2 SCR 848 [Chandler].

Ontario (Energy Board), ibid at para 66, citing Ontario (Children's Lawyer) $v$ Ontario (Information and Privacy Commissioner) (2005), 75 OR (3d) 309 (CA) at paras 42, 55, 58.

Ontario (Energy Board), ibid at para 67. 
however, could remove an important incentive for the decision maker to provide comprehensive reasons at the time of the original decision. Why would a public body write detailed and well-structured reasons if these could be supplemented in the event of judicial review? An administrative decision maker raising new arguments on judicial review could also take the opposing parties by surprise. ${ }^{31}$ Furthermore, an aggressive defence might diminish public perceptions of a tribunal's impartiality, particularly where the tribunal acts in a quasi-judicial role. ${ }^{32}$ With these concerns in mind, Justice Rothstein held that the principle of administrative finality should be a relaxed standard. It would not be offended in a case where a public body introduced arguments before the court to interpret its original decision or where those arguments were implicit within its original decision but not expressly articulated. ${ }^{33}$ An administrative decision maker would also be permitted to explain its processes and procedures on judicial review, even when these were not set out in its original reasons. ${ }^{34}$ Additionally, a public body would be permitted to respond to arguments raised by the opposing parties to better defend its decision. According to Justice Rothstein, responding to arguments raised in litigation would not constitute modifying the original decision or making a new decision. ${ }^{35}$ Justice Rothstein drew the line at a tribunal raising entirely new arguments on an appeal or judicial review, which would amount to improper bootstrapping.

Turning to the facts of the case, Justice Rothstein held that the Board had not engaged in improper bootstrapping. ${ }^{36}$ The Board's submissions highlighted certain information that was already apparent from the record or was in response to arguments that had been raised by the opposing parties. While the Board did not act improperly in law, Justice Rothstein cautioned that it should maintain a respectful tone in the litigation. ${ }^{37}$ Justice Rothstein singled out a submission made by the Board that a quashing order "would in all likelihood not change the result" of its original decision. ${ }^{38}$ Justice Rothstein observed that the comment could raise concerns about the Board's impartiality, which if taken too far could justify the reviewing court in refusing permission for the tribunal to participate in the proceedings. ${ }^{39}$

\section{IMPLICATIONS OF THE JUDGMENT FOR ADMINISTRATIVE LAW}

The Supreme Court of Canada's judgment in Ontario (Energy Board) carries a number of important implications for the law of judicial review in relation to the participation of tribunals in review litigation. At first glance, the judgment is concerning in that it partly revives the old distinction of characterizing public bodies as either administrative, judicial, or quasi-judicial. This distinction formerly played a key role in the threshold question of whether a duty of natural justice would be imposed on a public body. It was dispensed with in Ridge v. Baldwin ${ }^{40}$ when the House of Lords favoured an impact-oriented approach that more broadly considered the effect of a decision on an individual. The Supreme Court of

Ibid.

Ibid.

Ibid at para 68.

Ibid.

Ibid.

Ibid at para 70

Ibid at para 72 .

Ibid, citing Ontario (Energy Board), supra note 10 (Factum of the Appellant at para 99).

Ontario (Energy Board), ibid.

(1963), [1964] AC 40 (HL). 
Canada followed suit in Nicholson v. Haldimand-Norfolk Regional Board of Commissioners of Police, ${ }^{41}$ where a majority held that in determining whether natural justice applied, the reviewing court should consider the consequences of a decision on persons likely to be affected by it. The Supreme Court of Canada held that "the classification of statutory functions as judicial, quasi-judicial or administrative is often very difficult," and had generated unjust results where individuals affected by a decision of an administrative body received no procedural fairness at common law. ${ }^{42}$ Finally, in Cardinal v. Director of Kent Institution, ${ }^{43}$ the Supreme Court of Canada adopted the current formulation of the threshold for procedural fairness, as when an administrative decision affects a person's "rights, privileges or interests, ${ }^{\prime 4}$ which avoids characterizing the nature of the decision maker. Some remnants of the old distinction have remained, however, in Canadian law. For example, in the Baker case, the Supreme Court of Canada held that the "nature of the decision being made and the process followed in making it" $" 45$ is a factor for the reviewing court to consider as one part of a multifactorial analysis in determining the degree of procedural fairness required in the circumstances. In other words, the more the decision maker looks and acts like a court, the more procedural fairness will be required of it.

Without any discussion of the history of this problematic distinction, Justice Rothstein established that reviewing courts must characterize the decision maker as administrative or judicial/quasi-judicial in deciding whether and to what extent the tribunal should be permitted to participate as a litigation party. The more the tribunal looks and acts like a court, in the sense of adjudicating disputes over legal rights in an adversarial setting, the more reluctance the reviewing court should have about allowing its full participation in the appeal or judicial review. The rationale is straightforward and consistent with the continuing use of this distinction in Baker. Reviewing judges have a strong interest in ensuring that high standards of procedural fairness and impartiality are applied to public bodies that look and act like courts for the reason that individuals are more likely to interact with administrative decision makers than courts themselves. ${ }^{46}$ Tribunals therefore play an important role in shaping public perceptions of the administration of justice and adjudicative fairness. While there may be some conceptual difficulty in determining what constitutes an administrative versus a judicial/quasi-judicial decision maker, the Supreme Court of Canada was rightly concerned to ensure that tribunals perceived by the public as court-like bodies are held to a high standard of fairness and impartiality and that courts should be guided by this consideration. Moreover, the chief concern over unjust outcomes that prompted the abandonment of the distinction between administrative and judicial/quasi-judicial decision makers on the threshold question of the availability of procedural fairness does not extend to tribunal participation. The issue here is not whether individuals can obtain any protection of common law procedural fairness in relation to administrative decisions affecting them. Rather, the question is whether or not a tribunal can act as a litigation party in the event of an appeal or judicial review. The concern that an individual will not receive a fair process

(1978), [1979] 1 SCR 311.

Ibid at 325 .

[1985] 2 SCR 643.

Ibid at 653 .

Baker, supra note 1 at para 23.

See e.g., Lorne Sossin, "Access to Administrative Justice and Other Worries" in Flood \& Sossin, supra note 5, 211 at 226 who writes that this is especially true for low-income individuals. 
as a matter of law before the decision maker on account of a judicial characterization of the tribunal's nature is not at play.

Where the judgment does create real concern, however, is the wide latitude provided for public bodies to participate as full litigation parties in appeals and judicial review once characterized as administrative or regulatory decision makers. It does not appear that Justice Rothstein took a sufficient accounting of the risks that full tribunal participation could pose to administrative impartiality. An individual appearing before a tribunal may have little confidence in the tribunal's ambition to decide the matter fairly and impartially if it sees the same body actively defending itself in adversarial court challenges to its decisions in other cases. It is noteworthy that the Board in this case engaged Stikeman Elliott LLP, one of Canada's largest business law firms, to represent it before the Supreme Court of Canada. The significant resources expended by tribunals in fighting off court challenges could suggest that the tribunal is focused on defending whatever it does as right, even at significant expense, instead of a more appropriate (and impartial) focus on ensuring a fair process and a justifiable outcome in relation to the facts and the law.

The routine participation of a tribunal as a litigation party and the retention of litigation counsel could also encourage a defensive tribunal attitude in relation to its processes and decisions. An analogy can be made to a trial judge obtaining legal counsel to defend his or her judgment before an appellate court. Such involvement would suggest to the parties that the trial judge is principally concerned with vindication of what was done at first instance as opposed to ensuring the right outcome in law. While Justice Rothstein rightly observed that tribunals often hold specialized knowledge that is needed by a reviewing court to better understand the underlying decision, there are other ways in which the reviewing court could obtain this knowledge outside of the full participation of a tribunal in the litigation. One solution is legislative reform to provide for a public advocate to take on the role of the defending party in judicial review. ${ }^{47}$ Courts may also appoint amici curiae as part of their inherent jurisdiction where it is necessary to assist the court in discharging its work. ${ }^{48}$ The public advocate or amicus curiae could gather specialist information and present it in a more detached and impartial manner to the court. Such a system would better protect public confidence in administrative impartiality as it would interpose a layer, akin to an "institutional sieve," 49 between the tribunal and the reviewing court.

Another problematic aspect of the judgment is that the Supreme Court of Canada largely ignored the distinction between a statutory appeal of an administrative decision and the superior court's inherent supervisory power of judicial review. While this case involved a statutory appeal, the judgment appears to assume that the law relating to the litigation

47 The Supreme Court of Canada noted a legislatively-created public advocate in relation to utility boards in other provinces: Ontario (Energy Board), supra note 10 at para 60.

48 For a discussion of the role of amici curiae see Ontario v Criminal Lawyers' Association of Ontario, 2013 SCC 43, [2013] 3 SCR 3 at para 47 [emphasis in original], where the Supreme Court of Canada observes that, in the criminal law context, "amici should be used sparingly and with caution, in response to specific and exceptional circumstances" at para 47.

49 This language was used by the Supreme Court of Canada when it imposed a commission process to separate the judiciary from the government in relation to salary negotiations to better protect judicial impartiality: Reference re Remuneration of Judges of the Provincial Court of Prince Edward Island; Reference re Independence and Impartiality of Judges of the Provincial Court of Prince Edward Island, [1997] 3 SCR 3 at para 170. 
participation of tribunals on a statutory appeal and judicial review are one and the same..$^{50}$ This distinction, however, may later prove to be important in ways not yet considered. For example, statutory appeals often provide the appellate court with much broader grounds upon which to reverse the underlying decision in contrast with the limited inquiry of the court on judicial review. A broad statutory appeal could favour a more limited litigation role for the tribunal because the appellate court will engage in its own independent analysis of the law and the facts. Some statutory appeals might even provide a trial de novo, ${ }^{51}$ which sharply contrasts with a reasonableness assessment on judicial review marked by respectful deference to the reasoning of the public body. ${ }^{52}$ Applying a reasonableness standard on judicial review looks for justification, transparency, intelligibility, and that the decision falls within a range of possible, acceptable outcomes in relation to the facts and the law. ${ }^{53}$ In carrying out this deferential review, the court is seeking to understand the decision maker's thinking, which necessitates a much closer engagement with the reasoning of the public body that could be enhanced by its participation as a party in the judicial review litigation.

In terms of the content of tribunal arguments that can be properly made in an appeal or judicial review litigation, Justice Rothstein ruled out tribunal bootstrapping in that the tribunal could not raise "entirely new" arguments before the court. ${ }^{54}$ While this general approach should be applauded for supporting administrative finality and creating an incentive for tribunals to take better care in writing reasons at first instance, it provides little clarity in terms of its application for reviewing courts. The exercise involves a comparative assessment of the tribunal's original reasons and the reasons advanced by the tribunal before the court to determine whether the latter are "entirely new." What is or is not entirely new in relation to the original reasons appears to be highly subjective, as demonstrated by Ontario (Energy Board) itself. As noted earlier, the respondents in the case viewed the Board's arguments on appeal as inconsistent with the reasons it originally provided and the facts it had found. By contrast, Justice Rothstein viewed the same arguments as simply highlighting information already apparent from the underlying record or made in response to arguments raised by the opposing parties. While some measure of discretion for reviewing courts is appropriate to take account of the circumstances of each case, the Supreme Court of Canada's definition of bootstrapping, without further guidance, could result in unprincipled applications of what is or is not an "entirely new" reason.

On a related point, it is also not clear why Justice Rothstein limited the definition of bootstrapping to a situation in which a public body seeks to overcome a deficient decision with new arguments on appeal. The question of whether the decision is deficient has not yet been determined at the time of the appeal or judicial review. Instead, the tribunal might quite sensibly advance a number of new heads of analysis, even where it views its original decision as reasonable, in order to have a few additional "bites at the cherry" and increase the chance that one line of reasoning will be viewed favourably by the reviewing court. It should be made clear that improper bootstrapping captures this approach by including any

See e.g. the Supreme Court of Canada's treatment of the interpretation of the Copyright Act, RSC 1985, c C-42 by the Copyright Board of Canada in Society of Composers, Authors and Music Publishers of Canada v Bell Canada, 2012 SCC 36, [2012] 2 SCR 326.

Dunsmuir v New Brunswick, 2008 SCC 9, [2008] 1 SCR 190.

Ibid at para 47.

Ontario (Energy Board), supra note 10 at para 69. 
argumentation on appeal or judicial review that conflicts with or are not contemplated by the original reasons provided. Moreover, the exception to bootstrapping that applies for new arguments made by the tribunal on the basis that they respond to arguments advanced by the opposing party should be narrowly construed, as this could otherwise provide an open door for nearly limitless new arguments by the tribunal in response to the challenger's claim that its original decision was "unreasonable."

Finally, the principle of administrative finality adopted by Justice Rothstein is conceptually related to the doctrine of functus officio that applies to courts, as noted by the Supreme Court of Canada more than 25 years ago. ${ }^{55}$ The law would have benefited from a consideration of how the relaxed standard of administrative finality fits within a broader doctrine of functus officio, given shared policy concerns and major developments in administrative law over the past two decades. It may be that the Supreme Court of Canada was reluctant to more fully articulate the doctrine of administrative finality because of the great diversity among administrative decision makers that operate under a tremendous range of legislative frameworks. But this diversity should not hold back the development of the common law of judicial review, which could always operate in a context-sensitive way by considering relevant provisions of the enabling legislation. Courts should establish clear criteria for the principle of administrative finality, as applied to public bodies, to provide greater certainty in the law.

\section{INADEQUATE REASONS AND TRIbUnAl PARTicipation}

Ontario (Energy Board) raises interesting questions as to the proper litigation role of administrative tribunals on appeal or judicial review. The answers it provides, that tribunals can often fully participate as a party to the litigation and make a wide range of arguments before the court, is driven by a practical necessity. When the Supreme Court of Canada in Baker established the general duty for reasons to be provided as a matter of procedural fairness, it expanded the scope of when reasons are required under the common law. ${ }^{56}$ The result is that the vast majority of decision makers must now provide reasons in connection with many of their decisions. Baker plainly and convincingly laid out the significant benefits of this broader obligation. According to the Supreme Court of Canada, reasons ensure fair and transparent decision-making, improve substantive outcomes by ensuring that decisions are carefully thought out, help parties understand why the decision was made (and thus make parties feel like they were treated fairly and appropriately), and enable a reviewing court to review the record. ${ }^{57}$ They are also seen to value the dignity of the individual. ${ }^{58}$

The downside of capturing a wider range of administrative decision makers by enlarging the scope of the duty to provide reasons, however, is weakened expectations of the quality of the reasons for the decision. Other scholars have noted this trend. For example, Lorne

55 See e.g. Chandler, supra note 28 (where the Supreme Court held that functus officio must be applied to tribunals with more flexibility and less formalism than the courts given the distinction between appeal and judicial review at 860-64).

Baker, supra note 1 at para 43.

Ibid at paras 38-39.

See e.g. David Dyzenhaus, "Dignity in Administrative Law: Judicial Deference in a Culture of Justification" (2012) 17:1 Rev Const Stud 87. 
Sossin explores the lack of authenticity in reasons after Baker. According to Sossin, authentic reasons explain the "actual bases" for a decision that was made. ${ }^{59}$ Baker did not improve authenticity in reasons, but rather, weakened it. Sossin writes that "[w]hat has been celebrated as a 'culture of justification' has resulted in more kinds of reasons for more kinds of decisions than ever before, but too often this boils down to an acceptable boilerplate." $" 60$ In Sossin's view, the honesty of the reasons for a decision are often hidden behind the veil of boilerplate reasons that are seen as acceptable to administrative law — in other words, the reasons become what the decision maker thinks the court will want to hear instead of explaining the actual decision-making process and the genuine reasons for the decision that was made. ${ }^{61}$ Boilerplate reasons can, according to Sossin, compromise the "goal of Administrative Law as enabling those affected by a decision to understand why the decision in their case actually was reached ... and the exercise of public authority to be fair and just." 62

In addition to encouraging inauthentic boilerplate reasons, the general duty to provide reasons established in Baker has prompted a more permissive judicial approach to accepting what is provided by the administrative decision maker as its reasons. While Justice Rothstein expressed concern for the law to create incentives for quality reasons in Ontario (Energy Board), ${ }^{63}$ quality has been rejected by the Supreme Court of Canada as a stand-alone basis upon which to quash a decision. ${ }^{64}$ Poor quality, inadequate, and incomplete reasons proffered by an administrative decision maker are therefore accepted by courts as discharging the requirement of procedural fairness. This result was already anticipated in Baker where the Supreme Court of Canada observed that the newly broadened scope of the duty to give reasons should be applied with "sufficient flexibility" in the sense that the reviewing court should accept "various types of written explanations for the decision as sufficient." In Baker, the Supreme Court of Canada accepted the shorthand notes of the immigration officer as reasons, holding that reviewing courts must be pragmatic and "evaluate the requirements of the duty of fairness with recognition of the day-to-day realities of administrative agencies." Administrative decision makers are therefore free to pay little attention to the quality of their reasoning as there is little risk that a decision will be quashed on this basis under procedural fairness. And on substantive review, when applying a reasonableness standard, courts will go to great lengths to supplement inadequate reasons or even invent reasons they think the decision maker could have given.

Lorne Sossin, "A Tale of Two Discretions: Trinity Western University and Kanthasamy" (29 December 2015), Dean Sossin's Blog (blog), online: < deansblog.osgoode.yorku.ca/2015/12/a-tale-of-twodiscretions-trinity-western-university-and-kanthasamy/> [Sossin, "Two Discretions"]. Sossin writes that "[t] he great irony of Baker ... is that because the Immigration Officer in that case believed he was under no obligation to provide reasons, he shared the actual justification for denying a mother of four exemption from the then [Immigration Act, RSC 1985, c I-2, as repealed by Immigration and Refugee Protection Act, SC 2001, c 27] — which included profoundly discriminatory impulses against the applicant." Paul Daly has referred to boilerplate reasons by administrative decision makers as "probably inevitable and maybe incurable": Paul Daly, "Boilerplate Reasons" (29 May 2013), Administrative Law Matters (blog), online: <www.administrativelawmatters.com/blog/2013/05/29/boilerplate-reasons/>. Sossin, "Two Discretions," ibid.

Ibid.

Ibid.

Supra note 10 at para 67

Newfoundland Nurses' Union, supra note 4 at para 20.

Baker, supra note 1 at para 40.

Ibid at para 44. 
What incentive is there to produce well-written, quality reasons? Why do the hard work of writing clear, comprehensive, and logical reasons when the court will simply do the work for you? Baker struck a balance in favour of an increased scope of the duty to provide reasons at the cost of quality control. If anything counts as reasons, can it be claimed that reasons are truly providing the benefits expected of them? ${ }^{67}$ Canadian law on reasons is certainly problematic to the extent that individuals are required to challenge an administrative decision in court to properly understand why the original decision was made.

This is not a fanciful suggestion, as Ontario (Energy Board) demonstrates. The case can be seen as dealing with the continuing implications of Baker and the judicial acceptance of inadequate reasons. Because the actual reasons supplied by an administrative decision maker might not enable the reviewing court to fully understand the rationale for the underlying decision, either because they are boilerplate or are otherwise inadequate, tribunal participation in the litigation becomes necessary to assist the court in attempting to locate a reasonable interpretation of the decision. The "topping up" of a tribunal's original reasons by the tribunal on appeal or judicial review is really about helping the court better understand the rationale for the underlying decision so that it can take its commitment to deference seriously. The cost of this participation is not insignificant, as seen in Ontario (Energy Board) where public expense resulted from the Board's involvement as a party to the litigation. In addition, appeal and judicial review proceedings invariably become more complex and lengthy when a public body acts as a litigation party.

As noted earlier, tribunal participation also presents a real risk of impairing administrative impartiality, which could itself reduce public confidence in the administration of justice more generally. By now, the train is already well along the track with respect to the general obligation for public bodies to provide reasons. The challenge for the court in the circumstances is to find ways to signal to public bodies that quality of reasons also matters to administrative law, in the sense of being clear, comprehensive, logical, and authentic.

If reasons are to mean anything and provide the benefits promised by Baker's "culture of justification," they must be capable of being understood and adequately explain and justify the rationale for a decision that was made, without the court's help. The Supreme Court of Canada should revisit its holding in Newfoundland Nurses' Union and impose a sliding scale of quality as a legal requirement of procedural fairness, which could be informed by the importance of the decision to the individual affected by it. This approach would better ensure that the positive benefits of having reasons actually flow from the reasons provided by public bodies by setting minimum standards for important decisions. It would also limit public expense and litigation delay and complexity by reducing the need for tribunals to fully participate as parties in appeal or judicial review litigation. Less tribunal litigation participation would also better protect the principles of administrative finality and impartiality. 


\section{CONCLusion}

Since Baker, courts have grappled with the implications of the broadly applicable duty on public bodies to provide reasons, which has resulted in a lowering of the standard of what is seen as legally acceptable reasons. As a matter of procedural fairness, most anything provided by the decision maker will discharge the duty to provide reasons. On substantive review, when applying a reasonableness standard, reviewing courts will endeavour to work with what they get from the decision maker by supplementing inadequate reasons or even devising new reasons that the decision maker could have relied on. The opening of the door to the full participation of public bodies as parties to judicial review litigation is connected to these developments as it enables courts to obtain a better understanding of the underlying decision on appeal or judicial review where there are inadequate reasons. Ontario (Energy Board) is an important decision that carries significant implications for the law of judicial review, not least of which is likely to be increased litigation participation by public bodies. While this participation can further the interests of justice by ensuring fully informed decision-making in the appeal or judicial review, there is associated public expense and increased delay and complexity, particularly when administrative decision makers retain litigation counsel to defend the rightness of their actions such as in Ontario (Energy Board).

The Supreme Court of Canada is likely to be called upon to establish more restrictive rules relating to tribunal litigation participation in the event of the inconsistent or unprincipled application of its decision in Ontario (Energy Board) or diminished public confidence in administrative impartiality. But such changes would simply address the shortcomings of a by-product resulting from the main problem: the judicial acceptance of inauthentic and inadequate reasons. It would be much more effective for the Supreme Court of Canada to reduce the need for tribunal litigation participation altogether by seeking creative ways to ensure the production of authentic and high-quality reasons in the first place at the administrative level. 